\title{
A Heparin-binding Domain in the Amyloid Protein Precursor of Alzheimer's Disease Is Involved in the Regulation of Neurite Outgrowth
}

\author{
David H. Small, ${ }^{1}$ Victor Nurcombe, ${ }^{2}$ Gullveig Reed, ${ }^{1}$ Heidi Clarris, ${ }^{1}$ Robert Moir,${ }^{1}$ Konrad Beyreuther, ${ }^{3}$ and Colin \\ L. Masters ${ }^{1}$ \\ 'Department of Pathology and '2Department of Anatomy and Cell Biology, University of Melbourne, The Mental Health \\ Research Institute of Victoria, Parkville, Victoria, Australia 3052 and ${ }^{3}$ Laboratory of Molecular Biology, University of \\ Heidelberg, Heidelberg, Germany
}

\begin{abstract}
The amyloid protein precursor (APP) of Alzheimer's disease is synthesized as an integral transmembrane protein that is released from cells in culture following proteolytic cleavage. The function of released APP is not known, although there is evidence that the protein may bind to components of the extracellular matrix (ECM). In the present study, substratumbound APP stimulated neurite outgrowth in cultures of chick sympathetic and mouse hippocampal neurons. This effect was dependent upon the presence of substratum-bound heparan sulfate proteoglycans (HSPG). The effect of APP on neurite outgrowth was comparable to that of laminin. A 14 $\mathrm{K} \mathrm{N}$-terminal fragment of APP was found to bind heparin and a region close to the $\mathrm{N}$-terminus of APP (residues 96-110) identified as a potential heparin-binding domain based on secondary structure predictions and molecular modeling. Mutagenesis of three basic residues (lysine-99, arginine100 , and arginine-102) resulted in a recombinant protein (APPnop) with decreased heparin-binding capacity. A peptide homologous to the heparin-binding domain was synthesized and found to bind strongly to heparin and to inhibit binding of ${ }^{125}$-labeled APP to heparin $\left(\mathrm{IC}_{50} \approx 10^{-7} \mathrm{M}\right)$. The peptide blocked the effect of APP on neurite outgrowth $\left(I_{50} \approx 10^{-7}\right.$ $M)$, whereas two other peptides homologous to other domains in APP had no effect. The results indicate that the binding of APP to HSPG in the ECM may stimulate the effects of APP on neurite outgrowth.
\end{abstract}

[Key words: proteoglycan, development, ageing, amyloid plaque, heparan, adhesion]

Alzheimer's disease (AD) is characterized by the deposition of amyloid in extracellular and intracellular compartments of the cerebral cortex. Extracellular amyloid contains a protein ( $\beta \mathrm{A} 4)$ of 40-43 amino acids (Glenner and Wong, 1984; Masters et al., 1985), which is derived from a larger amyloid protein precursor (APP). APP has characteristics of an integral membrane protein,

Received Junt 10, 1993; revised Sept. 13, 1993; accepted Sept. 29, 1993.

This work was supported by the National Health and Medical Research Council of Australia, the Victorian Health Promotion Foundation, and the Aluminium Development Council. K.B. is supported by Deutsche Forschungsgemeinschaft and Bundesministerium für Forschung und Technologie.

Correspondence should be addressed to Dr. David H. Small, Department of Pathology, University of Mclbourne, Parkville, Victoria 3052, Australia.

Copyright (C) 1994 Society for Neuroscience $0270-6474 / 94 / 142117-11 \$ 05.00 / 0$ with a single transmembrane domain of hydrophobic amino acid residues close to the C-terminus (Kang et al., 1987). Multiple APP isoforms are produced by alternative mRNA splicing, some of which contain an extra 56 residue domain similar to Kunitz-type protease inhibitors (KPI) (Kitaguchi et al., 1988; Ponte et al., 1988; Tanzi et al., 1988; De Sauvage and Octave, 1989; Golde et al., 1990; König et al., 1992).

Cleavage of APP within the amyloidogenic sequence by the "APP secretase" results in the disruption of the $\beta A 4$ sequence and the release of the ectodomain with a relative molecular mass $\left(M_{r}\right)$ of 100-110 K (Palmert ct al., 1989; Wcidemann ct al., 1989; Esch et al., 1990; Sisodia et al., 1990; Small et al., 1991). The function of the APP detached from membranes is not known. Several studies suggest that secreted APP may bind to components of the extracellular matrix (ECM) (Schubert et al., 1989b,c; Klier et al., 1990; Small et al., 1992) such as the heparan sulfate proteoglycans (HSPGs) (Narindrasorasak et al., 1991; Small et al., 1992). APP can bind to heparin (Schubert et al., $1989 \mathrm{c}$ ), an analog of heparan sulfate, and to the carbohydrate and core protein of a basement membrane HSPG (Narindrasorasak et al., 1991). APP has also been reported to bind to other ECM proteins such as laminin (Narindrasorasak et al., 1992) and collagen (IV) (Breen, 1992). By analogy to fibroblast growth factor (FGF) (Klagsbrun and Baird, 1991; Rapraeger et al., 1991; Yayon et al., 1991), the binding of APP to HSPGs might act to protect the protein from degradation by proteases (Small et al., 1992).

Several studies have implicated APP in mitogenic (Saitoh et al., 1989; Schubert et al,, 1989a) and neurite outgrowth-promoting (Schubert et al., 1989b; Whitson et al., 1989, 1990; Yankner et al., 1989; Breen et al., 1991; Milward et al., 1992) processes in cultured cells. Recent studies suggest that APP may have excitoprotective effects on central neurons (Mattson et al., 1993) and that overexpression of APP may promote degeneration of embryonal carcinoma (Yoshikawa et al., 1992) and rat pheochromocytoma (PC12) cells (Milward et al., 1992) in vitro. A 40-residue domain of APP adjacent to the KPI region has been reported to stimulate the division of non-neuronal cells (Roch et al., 1992). Peptides derived from the amyloid region have been implicated in neurotoxic effects and in promoting survival and outgrowth from cultured neurons (Whitson et al., 1989; Yankner et al., 1989).

The aim of the present study was to examine the function of APP in primary cultures of neurons, and to determine whether 
the effect of APP on neurite outgrowth might be mediated through an interaction with HSPGs. We show that substratum-bound APP stimulates neurite outgrowth from primary cultures of both chick sympathetic and mouse hippocampal neurons, and that this effect requires the binding of HSPG to APP. We show the existence of heparin -binding domain close to the N-terminus of APP. This domain proves to be essential for the neurite outgrowth-promoting effects of substratum-bound APP.

\section{Materials and Methods}

Materials. Laminin and collagen type IV (from mouse EHS tumor) and human fibronectin were purchased from Collaborative Research Inc. (Bedford, MA). Heparitinase I (EC4.2.2.8, heparinase III), subtilisinCarlsburg, chondroitinase $\mathrm{ABC}$, chondroitinase $\mathrm{ACII}$, and bovine heart cytochrome c (type V) were from Sigma Chemical Co. (St. Louis, MO), and ${ }^{125} \mathrm{I}$-sodium iodide and ${ }^{35} \mathrm{~S}$-heparin were from Amersham (Sydney, Australia). Fetal calf serum (FCS) was from Commonwealth Serum Laboratories (Parkville, Australia). Dulbecco's modified Eagle's medium (DMEM) was from GIBCO/Bethesda Research Labs (Glen Waverley, Australia).

Purification of APP. APP was purified from postmortem human brain and from fetal calf serum (FCS) by ion-exchange, heparin-Sepharose, and hydrophobic interaction chromatography according to the method of Moir et al. (1992). The yield of purified APP was approximately 100 $\mu \mathrm{g}$ of protein per brain hemisphere or $50 \mu \mathrm{g}$ per liter of serum. The purity of the APP was checked by N-terminal amino acid sequencing and by silver staining of polyacrylamide gels and was found to be $>80 \%$ and $>95 \%$, respectively.

Preparation of HSPG from cell culture. HSPG was purified from the conditioned medium of dissociated cultures of neurons prepared from either embryonic day 10 (E10) or postnatal day 3 (P3) mouse brain (Drago et al., 1991; Nurcombe et al., 1993). Neural tissue was dissected free of adherent mesoderm and meninges, trypsinized, mechanically dissociated, and seeded into $100 \mathrm{~mm}$ plastic tissue culture dishes at a density of $5 \times 10^{7}$ cells per dish in $10 \mathrm{ml}$ of DMEM containing $10 \%$ $(\mathrm{v} / \mathrm{v})$ FCS. For metabolic labeling experiments, cells were incubated for 24-48 hr with $50 \mu \mathrm{Ci} / \mathrm{ml}$ of ${ }^{35} \mathrm{~S}$-sulfate (Amcrsham, Sydncy, Australia) in DMEM with low glucose $(1.0 \mathrm{gm} /$ liter $)$ and lacking sulfate, supplemented with dialyzed $10 \%(\mathrm{v} / \mathrm{v})$ FCS. Cultures were then chilled on ice and the culture medium removed. The labeled glycosaminoglycan in the culture medium was digested by treatment with $0.1 \mathrm{U} / \mathrm{ml}$ of chondroitinase $\mathrm{ABC}$ and chondroitinase $\mathrm{ACII}$ overnight at $37^{\circ} \mathrm{C}$ (Ishihara et al., 1993). The HSPG resistant to this treatment was then further purified by ion-exchange and size-exclusion chromatography.

Purification of HSPG. HSPG was purified according to previously described techniques (Yanagishita and Hascall, 1984; Needham et al., 1988) as modified by Nurcombe et al. (1993). Briefly, radiolabeled HSPG was separated from unincorporated sulfate by chromatography on a column $(2.5 \times 50 \mathrm{~cm})$ of Sephadex G-50, equilibrated, and eluted with a buffer containing $8 \mathrm{~m}$ urea, $0.15 \mathrm{M} \mathrm{NaCl}, 50 \mathrm{~mm} \mathrm{Na}$-acetate $(\mathrm{pH}$ $6.0)$, and $0.1 \mathrm{M} 6$-aminohexanoic acid. Void volume fractions $(50 \mathrm{ml})$ were pooled and supplemented with $0.5 \%(\mathrm{w} / \mathrm{v}) 3$-((3-cholamidopropyl)-dimethylammonio)-1-propane sulfonate (CHAPS), and then applied to a $5 \mathrm{ml}$ Econo-Pac Q cartridge (Bio-Rad, Richmond, CA). The column was washed with 20 column volumes of starting buffer containing $0.5 \%$ CHAPS and then bound material was subsequently eluted with a linear salt gradient $(0.15-1.0 \mathrm{M} \mathrm{NaCl})$ at a flow rate of $15 \mathrm{ml} / \mathrm{hr}$. The gradient volume was $50 \mathrm{ml}$. Peak fractions containing radioactivity were pooled, dialyzed against water, and lyophilized. HSPG was then further purified on a column $(1.0 \times 120 \mathrm{~cm})$ of Sepharose CL-4B (Pharmacia-LKB, Uppsala, Sweden) equilibrated and eluted with $4 \mathrm{M}$ guanidine- $\mathrm{HCl}$ in $0.05 \mathrm{M}$ Tris- $\mathrm{HCl}$ buffer $\left(\mathrm{pH} 7.0\right.$ ) containing $0.05 \mathrm{M} \mathrm{Na}_{2}$ sulfate, $0.2 \%(\mathrm{w} / \mathrm{v})$ CHAPS, $0.1 \mathrm{M} 6$-aminohexanoic acid, and $0.01 \mathrm{M}$ ethylenediaminetetraacetic acid (EDTA) at a flow rate of $10 \mathrm{~cm} / \mathrm{hr}$ according to the method of Threlkcld ct al. (1989). Peak fractions of radioactivity (eluting between 20 and $50 \mathrm{ml}$ ) were pooled, dialyzed against water, and lyophilized. The yield of HSPG was approximately $0.3 \mu \mathrm{g}$ per milliliter of conditioned medium and the purity was estimated to be $>88 \%$ based on its sensitivity to heparitinase digestion, and $>94 \%$ by nitrous acid sensitivity.

Peptide synthesis and purification. Peptides were obtained from Chi- ron Mimotopes (Melbourne, Australia) and then purified by reversedphase HPLC on a $0.4 \mathrm{~cm} \times 15 \mathrm{~cm}$ Novopak C18 column ( $4 \mu \mathrm{m}$ particle size). The sample $(1.0 \mathrm{mg}$ in $1.0 \mathrm{ml}$ of distilled water) was applied at a flow rate of $1.0 \mathrm{ml} / \mathrm{min}$ at ambient temperature, and the column washed for $1 \mathrm{~min}$ with $0.13 \%$ trifluoroacetic acid in water. Peptides were then eluted with a linear gradient of $0-100 \%$ acetonitrile containing $0.1 \%(\mathrm{v} /$ v) trifluoroacetic acid at a flow rate of $1.0 \mathrm{ml} / \mathrm{min}$ over $60 \mathrm{~min}$. The effluent from the column was monitored at $215 \mathrm{~nm}$. Fractions $(0.5 \mathrm{~min})$ were collected and peak fractions were pooled and evaporated to dryness using a Savant Speed Vac concentrator.

Cell culture. Sympathetic ganglia were dissected from E12 chick embryos according to the method of Edgar et al. (1981) and hippocampi were dissected from E1 8 mice according to the method of Goslin and Banker (1989). The tissue from each animal was digested in $2 \mathrm{ml}$ of trypsin-EDTA solution (CSL, Melbourne, Australia) at $37^{\circ} \mathrm{C}$ for $25 \mathrm{~min}$ Cells were triturated and single cell suspensions counted, collected, and then cultured in precoated 24-well plastic dishes at a density of $10^{4}$ cells $\mathrm{ml}$ in $0.5 \mathrm{ml}$ of DMEM containing $10 \%(\mathrm{v} / \mathrm{v}) \mathrm{FCS}$ and $5 \mathrm{ng} / \mathrm{ml}$ of nerve growth factor ( $2.5 \mathrm{~S} ;$ Sigma).

To determine the effect of various substrates on the growth of neurons, the wells of culture dishes were coated with different proteins by incubating with the protein of interest made up in PBS at room temperature. The order of application of each protein was first polyornithine $(0.1 \mathrm{mg} / \mathrm{ml})$ for $30 \mathrm{~min}$; second E10 or P3 HSPG, laminin, or fibronectin $(10 \mu \mathrm{g} / \mathrm{ml})$ for $2 \mathrm{hr}$; and then human brain or bovine serum APP (10 $\mu \mathrm{g} / \mathrm{ml}$ ) for $2 \mathrm{hr}$. In some experiments, peptides were added along with the APP. The molar ratio of peptide to APP was calculated assuming an $M_{r}$ for APP of $80 \mathrm{~K}$. After incubation, each well was washed three times with PBS before being used as a substrate for cell growth. Cultures were examined on the second day after plating under phase-contrast microscopy and selected fields captured for computer-assisted image analysis (MD30 Plus Image analysis system, Adelaide, Australia). The percentage of surviving cells in five ficlds of each well extending neurites longer than $20 \mu \mathrm{m}$ was measured. Five randomly selected fields containing a total of 100 cells were counted in each $16 \mathrm{~mm}$ culture well. A minimum of four culture wells for each treatment group were analyzed. Differences between the means of each group were analyzed using a one-way analysis of variance and a Tukey test for multiple comparisons.

Protease digestion of APP. Purified human brain APP $(0.5 \mathrm{mg}$ in 0.5 $\mathrm{ml} 50$ of mM sodium phosphate buffer, $\mathrm{pH} 7.0$ ) was digested by incubation with $5 \mu \mathrm{g}$ of a $1 \mathrm{mg} / \mathrm{ml}$ solution of subtilisin-Carlsberg (Protcase type VIII from Sigma) at $20^{\circ} \mathrm{C}$ for $1 \mathrm{hr}$. The digested protein was analyzed by heparin affinity chromatography.

Heparin affinity chromatography. APP $(1.0 \mathrm{ml}$ of a $20 \mu \mathrm{g} / \mathrm{ml}$ solution

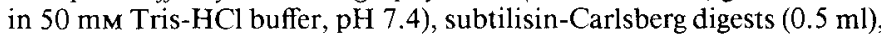
or peptides $(0.1 \mathrm{mg}$ in $1.0 \mathrm{ml}$ of distilled water) were applied to a $5 \mathrm{ml}$ Econo-Pac heparin column using an EconoSystem (Bio-Rad). The column was washed for $5 \mathrm{~min}$ with $50 \mathrm{~mm}$ Tris-HCl, $\mathrm{pH} 7.4$, at a flow rate of $1.0 \mathrm{ml} / \mathrm{min}$ and then eluted with a linear gradient of $0-1.0 \mathrm{M}$ sodium chloride in Tris buffer over $30 \mathrm{~min}$. The absorbance of the effluent was monitored at $280 \mathrm{~nm}$ or $215 \mathrm{~nm}$. One minute fractions were collected and the ionic strength of each fraction was calculated from conductivity measurements.

Size-exclusion HPLC. Heparin-binding fragments of APP generated by protease digestion and purified by heparin affinity chromatography were analyzed by size-exclusion HPLC on a $0.78 \times 30 \mathrm{~cm}$ column of Bio-Sil SEC-400 (Bio-Rad). The peak fractions (22-25) from the heparin affinity column were concentrated to $0.5 \mathrm{ml}$ by centrifugation through CF25 ultrafiltration cones (Amicon) and then applied to the size-exclusion column, which was equilibrated and eluted with a $0.1 \mathrm{M}$ sodium phosphate buffer, pH 7.0. Fractions $(0.5 \mathrm{ml})$ were collected and an aliquot from each fraction $(20 \mu \mathrm{l})$ was analyzed by Western blotting using a monoclonal antibody (22C11) (Weidemann et al., 1989) on a $15 \%$ polyacrylamide gel in the presence of sodium dodecyl sulfate (Laemmli, 1970).

Theoretical analysis of APP strusture. To predict the secondary structure of the N-terminal 240 amino acid residues of APP, the amino acid sequence was analyzed using a computer program (MELPROT) designed at the University of Melbourne, Department of Biochemistry (Raj et al., 1988; Sikaris et al., 1989). This program compares various algorithms for $\alpha$-helix and $\beta$-structure (Chou and Fasman, 1978), $\beta$-turn (Chou and Fasmian, 1979), hydrophilicity (Hopp and Woods, 1981), and atomic flexibility (Karplus and Schulz, 1985) to assess the likelihood of secondary structure

The three-dimensional structure of the putative heparin-binding do- 

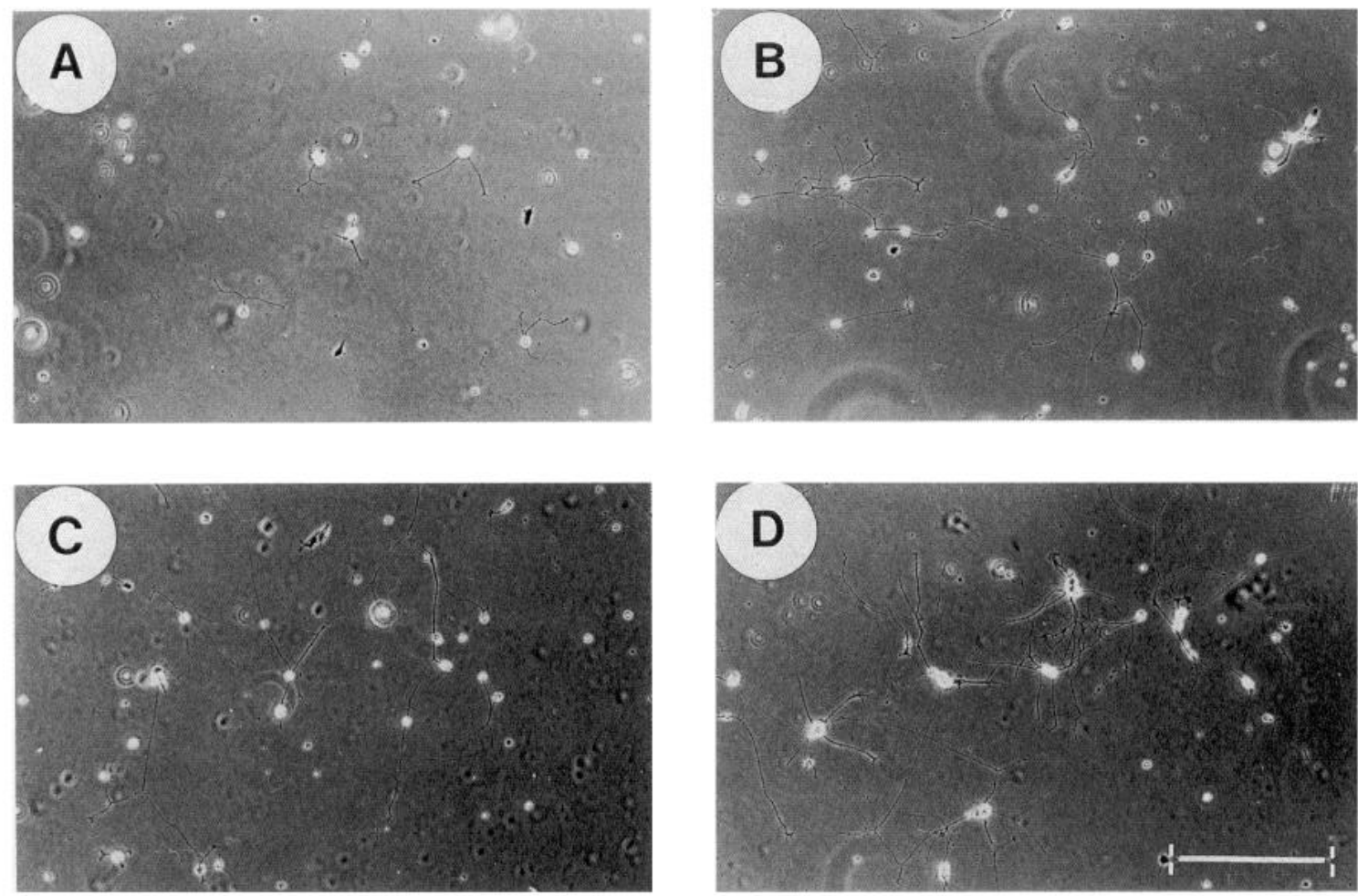

Figure 1. Phase-contrast micrograph of E12 chick sympathetic neurons maintained in culture for 48 hr on various protein substrates. Culture dishes were coated with polyornithine alone $(A)$, polyornithine + P3 HSPG $(B)$, polyornithine + bovine serum APP $(C)$, or polyornithine + P3 HSPG + bovine serum APP $(D)$. Scale bar, $100 \mu \mathrm{m}$.

main of APP was modeled using the INSIGHT II program (Biosym, San Diego, CA). The DISCOVER module was used for energy minimization. The peptide acetyl-asn-trp-cys-lys-arg-gly-arg-lys-gln-cys-lys-amide containing a disulfide bond between the two cysteine residues was constructed using the BIOPOLYMER module and then subjected to energy minimization to obtain several feasible models of the binding site. The lowest-energy structure $(-47 \mathrm{kcal} / \mathrm{mol})$ was obtained after approximately 100,000 iterations.

Site-directed mutagenesis and expression of recombinant APP. Sitedirected mutagenesis was carried out by polymerase chain reaction (PCR) using a plasmid expression vector (pAPP-695) previously described by Weidemann et al. (1989). Methods were essentially as described by Ausubel et al. (1992). For the first PCR, the forward primer (5'CCATGTTCTGTGGCAGACTG-3') was identical to bases 104-123 in the $\mathrm{APP}^{695}$ sequence (Kang et al., 1987), and the reverse primer (5'GCACTGCTTGCCGCCCTGGTTGCACCAG-3') complementary to bases $288-315$ of the APP ${ }^{695}$ sequence, except for the bases at positions 297,299 , and 304, which were changed to yield a sequence encoding a mutated form of APP expressing an asparagine instead of a lysine residue at position 99, a glutamine instead of an arginine at position 100 , and a glycine residue instead of an arginine at position 102. The expression vector was used as a template for the first PCR. PCR amplification was carried out for 36 cycles using an FTS-1 thermal cycler (Corbett Research, Lidcombe, Australia). Each cycle consisted of $1.0 \mathrm{~min}$ at $94^{\circ} \mathrm{C}$, $1.0 \mathrm{~min}$ at $55^{\circ} \mathrm{C}$, and $2.0 \mathrm{~min}$ at $72^{\circ} \mathrm{C}$. The purified 212 base pair (bp) DNA from the first PCR was then used to provide a forward primer in a second PCR reaction. The reverse primer for the second PCR reaction (5'-GTCGGAATTCTGCATCCATC-3') was complementary to bases 1785-1804 of the APP ${ }^{695}$ sequence. The second PCR amplification was carried out for 36 cycles. Each cycle consisted of $1.0 \mathrm{~min}$ at $94^{\circ} \mathrm{C}, 1.0$ min at $60^{\circ} \mathrm{C}$, and $3.0 \mathrm{~min}$ at $72^{\circ} \mathrm{C}$. Both the pAPP- 695 and the 1.7 kilobase $(\mathrm{kb})$ product from the second PCR reaction were digested with AccI and BglII. The digested PCR product was cloned into pAPP-695 at the AccI and BglII restriction sites. The sequence of inserted DNA in the recombinant plasmid colonies was confirmed by double-stranded sequencing using the forward primer from the first PCR reaction to prime the sequencing reaction (Slatko and Albright, 1992).
HeLa cells were cotransfected using the calcium phosphate method as described previously (Weidemann et al., 1989). The cells were grown in $75 \mathrm{~cm}^{2}$ plastic flasks containing $10 \mathrm{ml}$ of DMEM containing $10 \%(\mathrm{v} /$ v) FCS. Conditioned medium obtained $2 \mathrm{~d}$ after transfection was collected from three flasks and dialyzed against 2 liters of $50 \mathrm{~mm}$ Tris- $\mathrm{HCl}$ buffer $(\mathrm{pH} 7.4)$, overnight at $4^{\circ} \mathrm{C}$, and then analyzed by heparin affinity chromatography.

Binding assays. Binding assays were performed in a 96-well ELISA plates (Greiner Labortechnik, Frickenhausen, Germany). Human brain APP was iodinated with carrier-free ${ }^{125} \mathrm{I}-\mathrm{NaI}$ using the Chloramine T method (Hunter and Greenwood, 1962) to a specific radioactivity of 12 $\mu \mathrm{Ci} / \mu \mathrm{g}$. Wells were incubated with $0.1 \mathrm{ml}$ of heparin $(1 \mathrm{mg} / \mathrm{ml})($ Sigma grade II from porcine intestinal mucosa) in phosphate-buffered saline (PBS) overnight at $4^{\circ} \mathrm{C}$. The wells were washed twice with $0.33 \mathrm{ml}$ of PBS and then incubated for $1 \mathrm{hr}$ at ambient temperature with $0.33 \mathrm{ml}$ of $1.0 \%(\mathrm{w} / \mathrm{v})$ bovine serum albumin (BSA) in PBS to block all nonspecific binding sites. Wells were washed twice with $0.33 \mathrm{ml}$ of PBS and then incubated with $0.10 \mathrm{ml}$ of ${ }^{125} \mathrm{I}$-labeled APP $\left(7 \times 10^{6} \mathrm{dpm} / \mathrm{ml}\right)$ containing $1 \%(\mathrm{w} / \mathrm{v}) \mathrm{BSA}$ in PBS for $2 \mathrm{hr}$ at $37^{\circ} \mathrm{C}$. Each well was then washed five times with $0.3 \mathrm{ml}$ of PBS and then incubated for $1 \mathrm{hr}$ with $0.1 \mathrm{ml}$ of $50 \mathrm{~mm}$ Tris- $\mathrm{HCl}$ (pH 7.4) containing $0.4 \mathrm{M} \mathrm{NaCl}$ to release the APP bound to heparin. The binding of ${ }^{125}$ I-APP in wells not coated with heparin was also determined. ${ }^{125}$ I was counted in an LKB 1261 Multigamma counter.

\section{Results}

\section{Effect of APP and HSPG on neurite outgrowth}

As APP may interact with HSPGs (Small et al., 1992), we examined the effect of APP and HSPG on the growth of sympathetic neurons prepared from E12 chick embryos. Plastic 24well tissue culture plates were first coated with polyornithine and then with combinations of APP, HSPG, laminin, and fibronectin. On dishes coated with HSPG purified from cultures 


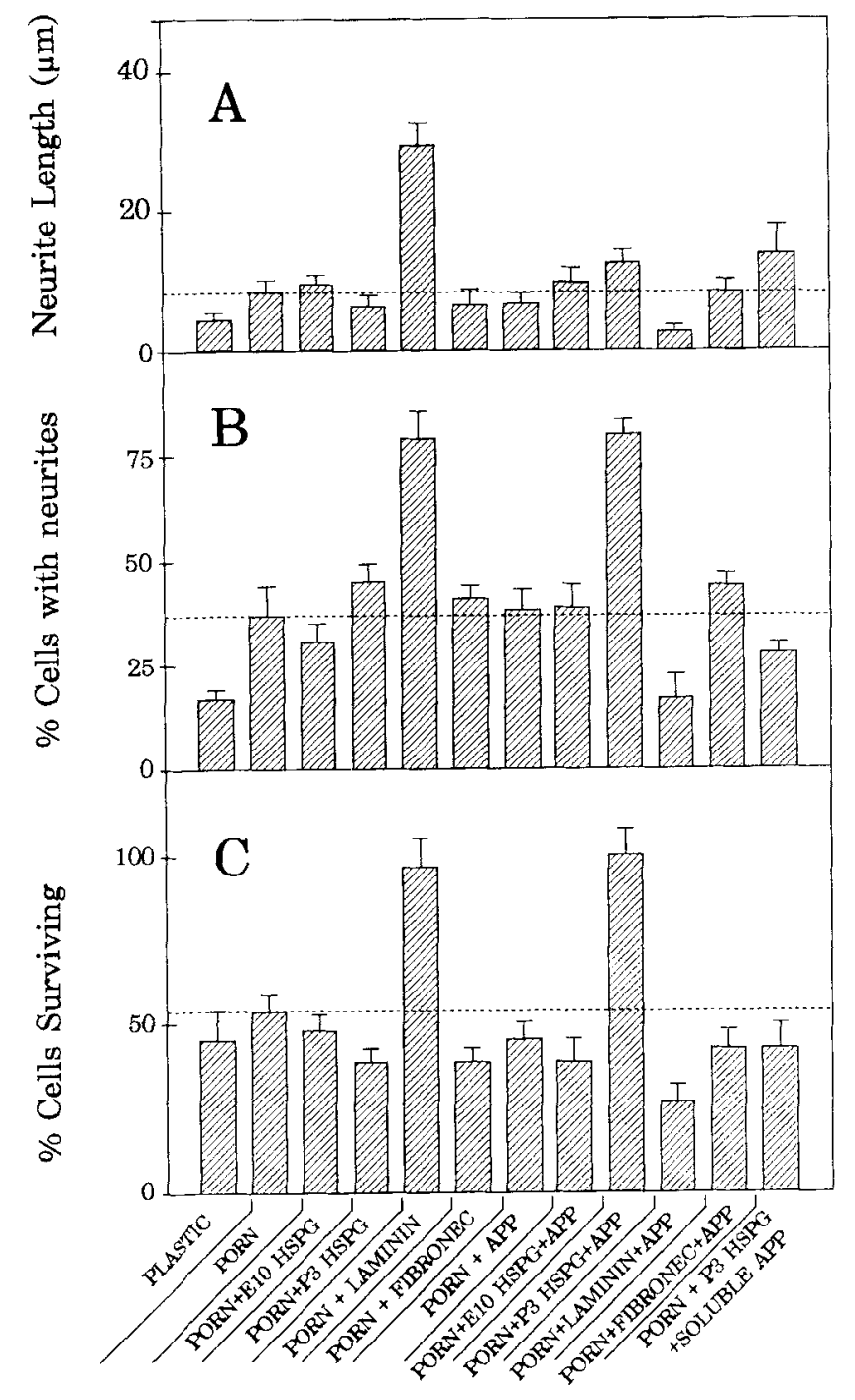

Figure 2. Quantitative image capture analysis of representative neurite outgrowth from E12 chick sympathetic neurons maintained in culture for $48 \mathrm{hr}$ on various protein substrates. Figure shows the effect of various protein substrates on ncuritc length $(A)$, percentage of cells with neurites $(B)$, and percentage of cells surviving $(C)$. Data are expressed as the mean value $( \pm$ SEM) obtained from at least four culture wells in which the percentage of cells with neurites greater than $20 \mu \mathrm{m}$ was determined. The experiment was repeated three times. Five randomly selected fields containing a total of 100 cells were counted in each $16 \mathrm{~mm}$ culture well. APP was purified from human brain according to Moir et al. (1992). PORN, Polyornithine; FIBRONEC, fibronectin; PLASTIC, not cultured on protein substrate. In one set of incubations, APP was added in solution (soluble APP) in the growth medium rather than being coated on the surface of the culture dishes.

of P3 mouse brain cells and with APP, we observed an increase in the percentage of cells bearing at least one neurite greater than $20 \mu \mathrm{m}$ in length, that is, 2 cell diameters, when cells were maintained in culture for $48 \mathrm{hr}$ (Fig. 1). The neurite outgrowth was quantified by computer-assisted image analysis and the data were analyzed by a one-way ANOVA and a Tukey test for multiple comparisons. The stimulatory effect of APP and HSPG on neurite outgrowth was found to he comparable to that achieved by laminin alone (Fig. 2). The percentage of neurons with neurites in the presence of APP and HSPG was significantly different $(P<0.05)$ from the control group containing polyornithine

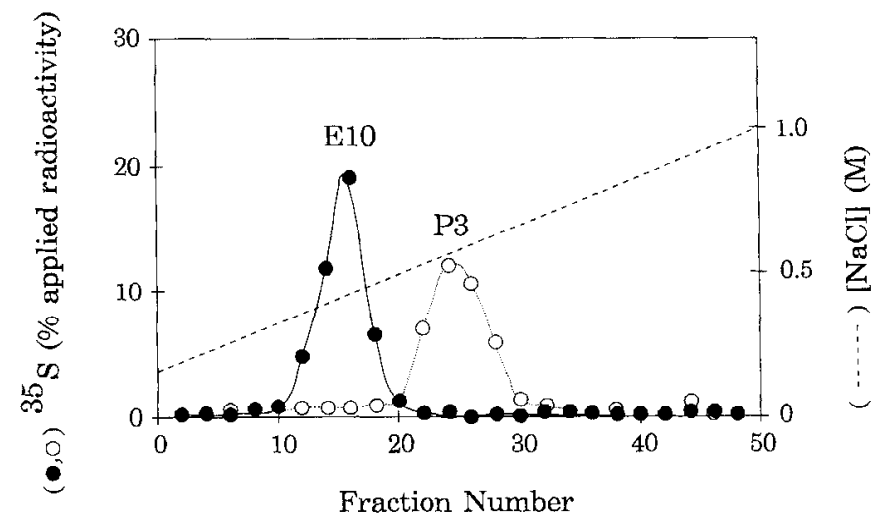

Figure 3. Ion-exchange chromatography of ${ }^{35}$-labeled HSPG from E10 and P3 mouse brain neurons. Cultures of dissociated neurons prepared from E10 and P3 mouse brain were labeled with $50 \mu \mathrm{Ci} / \mathrm{ml}$ of ${ }^{35} \mathrm{~S}$-sulfate for $24 \mathrm{hr}$. Labeled HSPGs (approximately $5000 \mathrm{dpm}$ for E10 HSPG and 15,000 dpm for P3 HSPG) were then purified from the conditioned culture medium on a $5 \mathrm{ml}$ Econo-Pac Q cartridge using an EconoSystem (Bio-Rad). The cartridge was eluted at a flow rate of 15 $\mathrm{ml} / \mathrm{hr}$ with a linear salt gradient $(0.15-1.0 \mathrm{M} \mathrm{NaCl})$. Fractions $(1 \mathrm{ml})$ were collected and alternate fractions assayed for radioactivity. Figure shows the recovery of radioactivity from the column expressed as a percentage of the applied radioactivity.

alone. In contrast, APP or HSPG alone did not significantly stimulate neurite outgrowth (Figs. 1, 2).

Not all forms of HSPG, when added in combination with APP, were capable of inducing neurite outgrowth. HSPG purified from $\mathrm{P} 3$ mouse brain stimulated neurite outgrowth, whereas HSPG purified from either E10 (a developmental stage before the major period of neurite outgrowth) mouse brain (Fig. 2) or commercially acquired HSPG from liver (data not shown) did not induce neurite outgrowth. This result suggested that specific (developmentally regulated) HSPGs may be required for stimulating the action of APP on neurite outgrowth. Consistent with this idea, we found that HSPGs purified from E10 mouse brain cell cultures differed in their ion-exchange chromatography elution profile from those purified from P3 cultures (Fig. 3). E10 HSPG also differed in its molecular weight profile upon sizeexclusion chromatography (data not shown).

\section{Identification of a heparin-binding domain}

To identify regions of APP containing heparin-binding domains, human brain APP was digested with $10 \mu \mathrm{g} / \mathrm{ml}$ of subtilisinCarlsberg for $1 \mathrm{hr}$ to cleave the APP into lower-molecularweight fragments. Heparin-binding fragments were purified from the protease digest by affinity chromatography (Fig. 4) and the fractions containing bound protein (22-25) pooled and analyzed by size-exclusion HPLC on a column $(0.78 \times 30 \mathrm{~cm})$ of Protein Pak 125 (Millipore-Waters, Bedford, MA). Fractions eluting from the HPLC were analyzed by Western blotting using a mouse monoclonal antibody $(22 \mathrm{C} 11)$, which recognizes a domain within the first $100 \mathrm{~N}$-terminal amino acid residues. The aim of this approach was to identify low-molecular-weight fragments of APP containing both a heparin-binding domain and the epitope for the $22 \mathrm{Cl} 1$ antibody.

An immunoreactive fragment was identified that possessed an $M_{r}$ estimated to be approximately $14 \mathrm{~K}$ by SDS gel electrophoresis (Fig. 5). Based on its elution volume from the sizeexclusion column, the native $M_{r}$ of the APP fragment was also estimated to be $14 \mathrm{~K}$. Assuming that a $14 \mathrm{~K}$ polypeptide does 


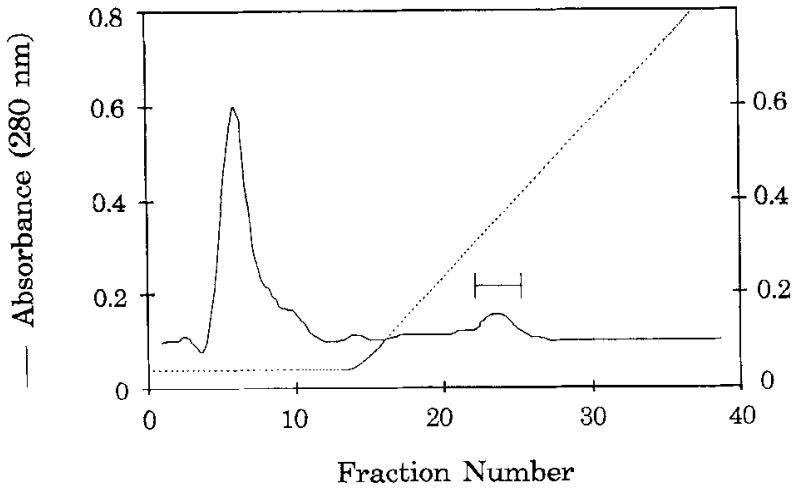

Figure 4. Heparin affinity chromatography of subtilisin-Carlsberg digested APP. Human brain APP $(0.5 \mathrm{mg})$ was digested with subtilisinCarlsberg $(5 \mu \mathrm{g})$ for $1 \mathrm{hr}$ and then the digest applied to a $5 \mathrm{ml}$ EconoPac heparin cartridge. The cartridge was eluted with a linear gradient $(0-1.0 \mathrm{M} \mathrm{NaCl})$ over $30 \mathrm{~min}$ at a flow rate of $1.0 \mathrm{ml} / \mathrm{min}$ using an EconoSystem (Bio-Rad). Figure shows the ionic strength of the effiuent as calculated from conductivity measurements. The bar shows the peak fractions (22-25) that were pooled for further analysis.

not contain more than 200 amino acid residues, the results of this expcriment indicated that a heparin-binding domain exists within the first 300 amino acid residues from the $\mathrm{N}$-terminus. Analysis of this region of the APP amino acid sequence (Kang et al., 1987) revealed only one domain of the protein (residues 99-110) near the N-terminus containing a cluster of basic residues likely to be a heparin-binding site. This region contained the consensus sequence (BBXB) for heparin binding as proposed by Cardin and Weintraub (1989).

To examine the conformation of APP in the region of residues 96-110, we used a computer-assisted program (MFI PROT), which employs standard algorithms ( $\alpha$-helix, $\beta$-structure, $\beta$-bend, hydrophilicity, and atomic flexibility) to predict secondary structure (Raj et al., 1988; Sikaris et al., 1989). The region between residues 98 and 105 yielded high flexibility, $\beta$-bend, and hydrophilicity scores (Fig. 6). The results from the secondary structure analysis and the presence of two cysteine residues on either side of this region suggested that this putative heparin-binding

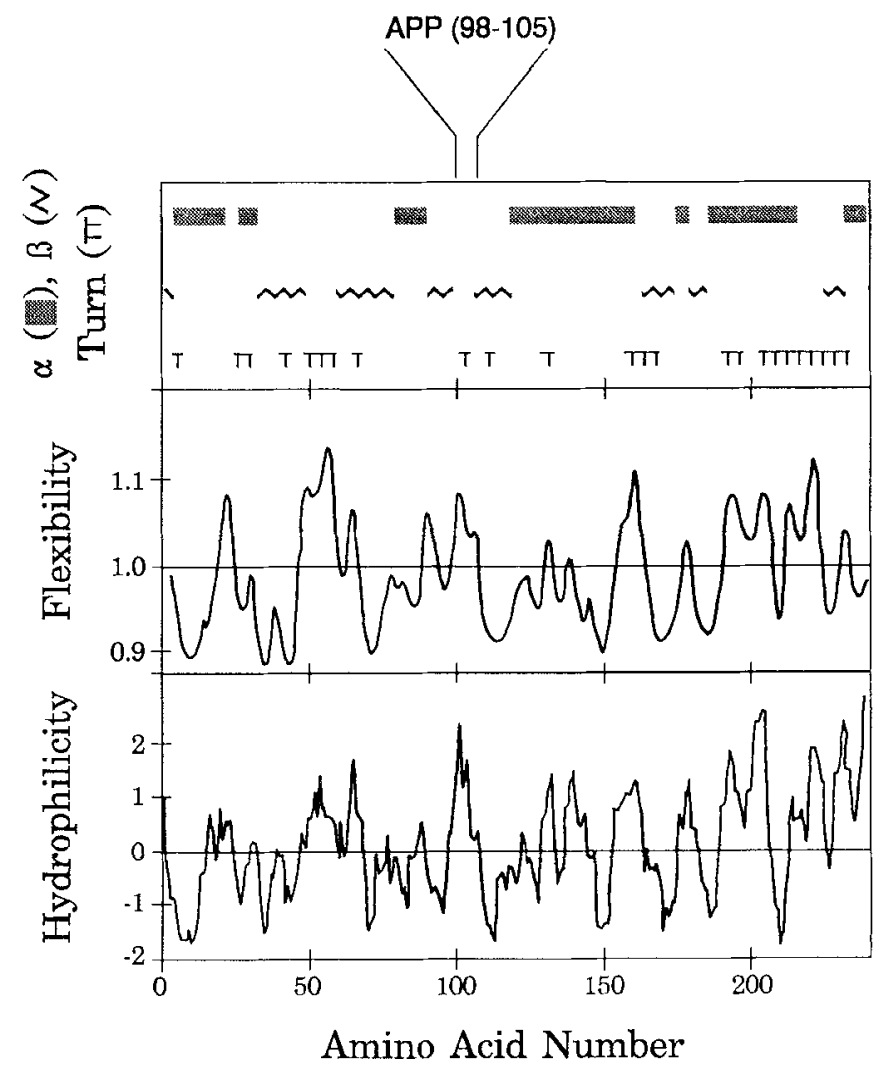

Figure 6. Results of predictive algorithm profiles for the first 240 amino acid residues of human APP. Figure shows the prediction of $\alpha$-helix, $\beta$-structure, and $\beta$-turn according to the methods of Chou and Fasman $(1978,1979)$. The atomic flexibility index was according to the method of Karplus and Schulz (1985), while the hydrophilicity index was according to Hopp and Woods (1981). Figure also shows the region of APP spanning residues 98-105 that yielded high scores for flexibility and hydrophilicity and was not predicted to contain appreciable $\alpha$-helix or $\beta$-structure.

domain of APP might form a loop, which might be stabilized by a disulfide bond between the two cysteine residues.

To explore this possibility further, we used molecular graphics to model the structure of a peptide homologous to APP between

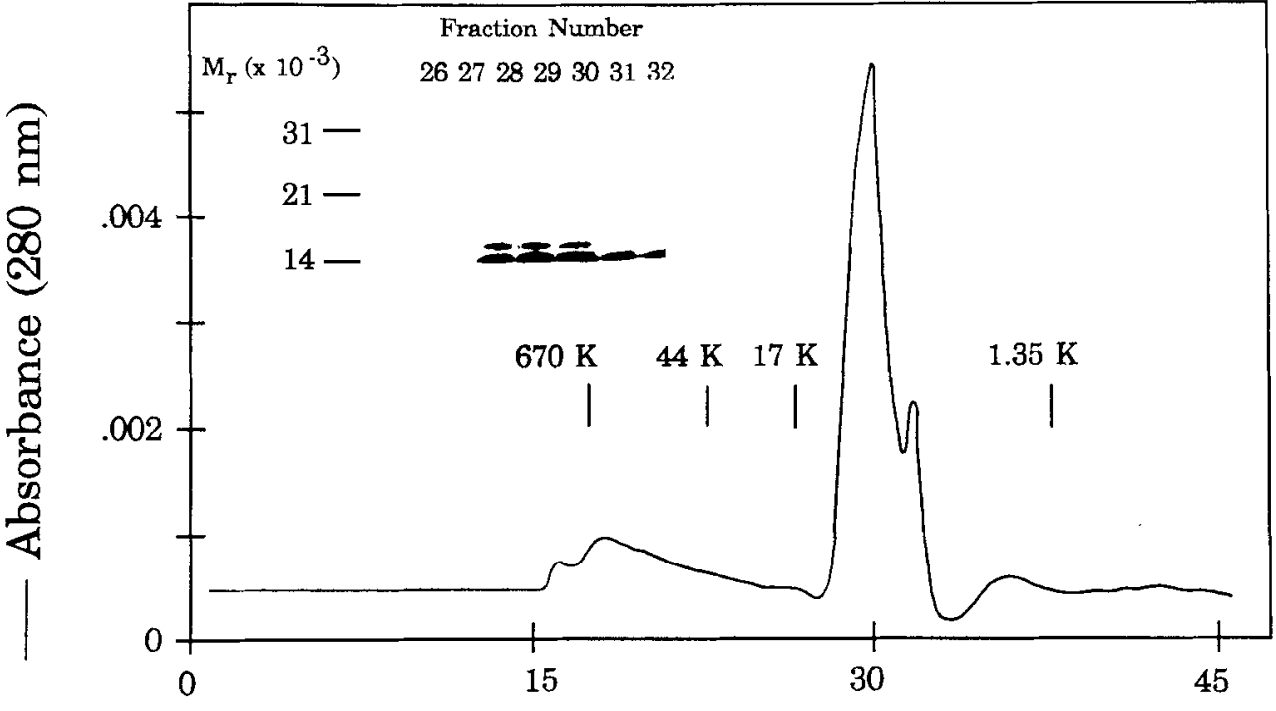

Fraction Number
Figure 5. Size-exclusion HPLC of heparin-binding fragments of APP on a column $(0.78 \times 30 \mathrm{~cm})$ of ProtcinPak 125 (Millipore-Waters). The column was eluted at a flow rate of $1.0 \mathrm{ml} /$ $\mathrm{min}$, and $1.0 \mathrm{ml}$ fractions were collected. The elution positions of molecular weight standards thyroglobulin $(670 \mathrm{~K})$, ovalbumin $(44 \mathrm{~K})$, myoglobin $(17 \mathrm{~K})$, and cyanocobalamin $(1.35 \mathrm{~K})$ are shown. Inset shows the analysis of fractions $26-32$ by Western blotting using a monoclonal antibody $(22 \mathrm{Cl} 1)$. An immunoreactive fragment of $14 \mathrm{~K}$ eluted in fractions $28-32$. 


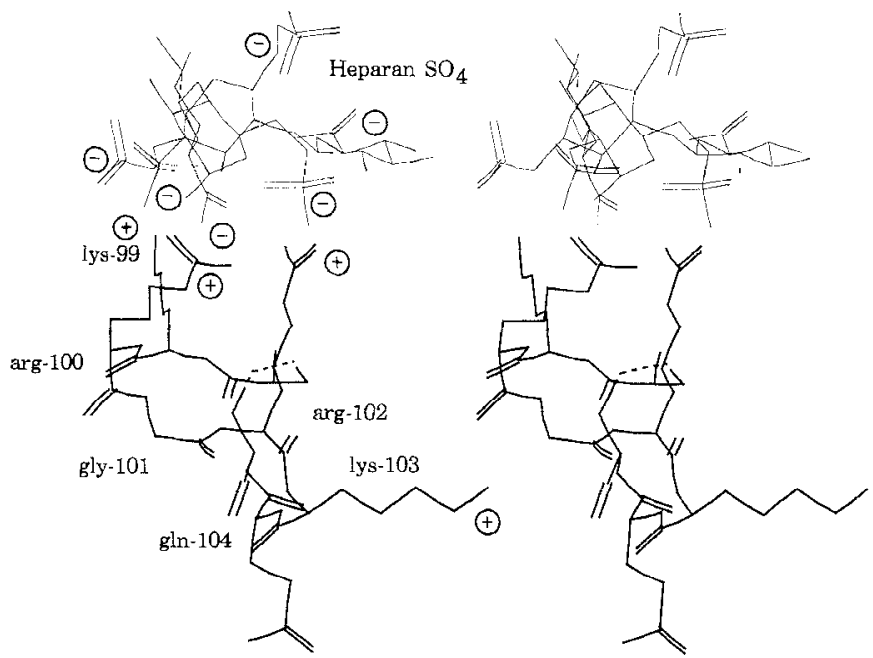

Figure 7. A predicted stereo structure of APP in the region of the putative heparin-binding domain. The figure shows a three-dimensional representation of the polypeptide backbone and side chains of APP in the region between cys-98 and cys-105. Three amino acid residues (lys99 , arg-100, and arg-102) could be aligned with negatively charged groups on the surface of heparan sulfate. The structure of APP and a heparan sulfate containing two repeat disaccharide subunits of glucuronate- $\beta 1,3-N$-sulfate glucosamine-6-sulfate were modeled with the INSIGHT II program.

asparagine- 96 and lysine-106 containing a disulfide bond between cysteine-98 and cysteine-105. The theoretical peptide was subjected to energy refinement using the DISCOVER module of the INSIGHT II program. After up to 100,000 gradient minimization steps, the lowest-energy structures were examined. The lowest-energy structure obtained adopted a conformation in which three amino acid residues of the loop aligned precisely with negatively charged groups on the surface of heparan sulfate (Fig. 7),

\section{Site-directed mutagenesis of the putative heparin-binding domain}

As molecular graphics studies suggested the importance of lysine-99, arginine-100, and arginine-102 for heparin binding, we used site-directed mutagenesis to produce a recombinant form of APP with the residues at positions 99, 100, and 102 mutated to asparagine, glutamine, and glycine, respectively. Two PCR steps were used to generate a double-stranded DNA fragment containing the appropriate mutations (Fig. 8A). A plasmid expression vector (pAPP-695) was used as a template for the PCR. The reverse primer contained three base changes designed to mutate the anino acid residues at positions 99,100 , and 102 . The PCR product was then used to provide the forward primer for a second PCR that yielded a larger $(1.7 \mathrm{~kb})$ DNA fragment encompassing two unique restriction sites (Accl and BglII). The second PCR product was digested with AccI and BglII and then inserted into the pAPP-695 vector. Recombinant clones were selected and used for transient transfection of HeLa cells. The expressed mutant protein (APPnep) was then analyzed by heparin affinity chromatography (Fig, 8B). Mutation of the three basic amino acid residues at positions 99,100 , and 102 were found to decrease heparin binding, as APPhep eluted earlier $(21 \mathrm{~min})$ from the affinity column (i.e., at a lower salt concentration) than the nonmutated APP (23 min).
Table 1. Ionic strength required to elute proteins and peptides from a heparin affinity column

\begin{tabular}{|c|c|}
\hline Substance & $\begin{array}{l}\text { Ionic } \\
\text { strength } \\
\text { (M) }\end{array}$ \\
\hline \multicolumn{2}{|c|}{ Acetyl-NWCKRGRKQCKTHPH-amide (cyclized } \\
\hline $\left.\operatorname{APP}_{96-110}\right)$ & 0.34 \\
\hline Human serum APP & 0.30 \\
\hline Bovine serum APP & 0.30 \\
\hline Laminin (mouse EHS tumor) & 0.30 \\
\hline Human plasma fibronectin & 0.27 \\
\hline \multicolumn{2}{|c|}{ Acetyl-NWCKRGRKQCKTHPH-amide (uncyclized } \\
\hline $\left.\mathrm{APP}_{96-1 ; 0}\right)$ & 0.26 \\
\hline Collagen IV (mouse EHS tumor) & 0.22 \\
\hline Acetyl-APP $317-331$-amide & 0.16 \\
\hline Acetyl-APP ${ }_{419-435}$-amide & 0.15 \\
\hline $\begin{array}{l}\text { Acetyl-fibronectin }{ }_{1782-1792} \text {-amide ( } \\
\text { heparin-binding site) }\end{array}$ & 0.11 \\
\hline Bovine cytochrome $\mathrm{c}$ & 0.11 \\
\hline $\mathrm{APP}_{645-655}$ & 0.10 \\
\hline Acetyl-APP ${ }_{606-619}$-amide & $<0.05$ \\
\hline $\mathbf{A P P}_{6,1-6,38}$ & $<0.05$ \\
\hline$\left[\right.$ ala $\left.^{73}\right] \mathrm{APP}_{63.73}$ & $<0.05$ \\
\hline$\left[\right.$ ala $^{174}$, tyr $\left.^{175}\right] A P P_{174-185}$ & $<0.05$ \\
\hline$\left[\right.$ ala $^{359}$, tyr $\left.^{360}\right]$ APP $(359-371)$ & $<0.05$ \\
\hline
\end{tabular}

Peptides or APP were applied to a heparin affinity column and then eluted with a linear gradient of $0-1.0 \mathrm{M}$ sodium chloride. The ionic strength of peak fractions was determined using a conductivity meter. APP was purified from fetal bovine or human serum by ion-exchange and heparin-Sepharose affinity and hydrophobic interaction chromatography (Moir et al., 1992). The standard one-letter abbreviations for amino acids are used. Some of the peptides examined were blocked with an acetyl group or an amide group (amide) at the $\mathrm{N}$ - and $\mathrm{C}$-termini, respectively. Values shown for ionic strength are the means of three determinations. The difference between determinations was less than two significant figures; hence, error values are not shown.

\section{Binding of a cyclized peptide (APP $\left.{ }_{40-110}\right)$ to heparin}

A peptide (acetyl-NWCKRGRKQCKHPH-amide, APP $96-110$ ) homologous to this heparin-binding domain was synthesized for testing in vitro. To hold the peptide in a loop conformation, the peptide was cyclized by introducing a disulfide bond between the two cysteine residues. The peptide was then purified by reversed-phase HPLC.

Initially, to compare the relative affinities of proteins and peptides for binding to heparin, we examined the concentration of $\mathrm{NaCl}$ required to elute the protein or peptide from a heparin affinity column. Compounds were eluted with a linear gradient of salt (0-1.0 M NaCl over $30 \mathrm{~min})$. Using this approach, APP eluted at an ionic strength of $0.3 \mathrm{M}$ (Table 1). The concentration of salt that was needed to elute APP was similar to that reported in previous studies (Schubert et al., 1989c; Potempska et al., 1991). Other ECM-associated heparin-binding proteins such as laminin, fibronectin, and collagen type IV eluted at similar or slightly lower ionic strengths. We also examine the binding of cytochrome $\mathrm{c}$, a highly basic protein that bound nonspecifically to the heparin column through ionic interactions. Cytochrome c eluted at low ionic strength $(0.11 \mathrm{M})$.

The cyclized $\mathrm{APP}_{96-110}$ peptide bound strongly to the heparin affinity column, as it was eluted only an ionic strength of $>0.34$ $\mathrm{M}$ (Table 1). The cyclized peptide bound more strongly to the 


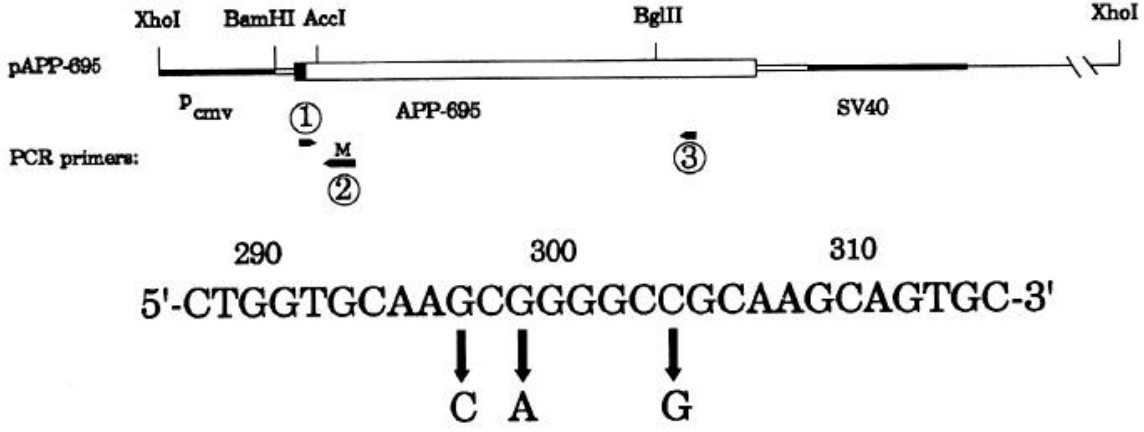

100

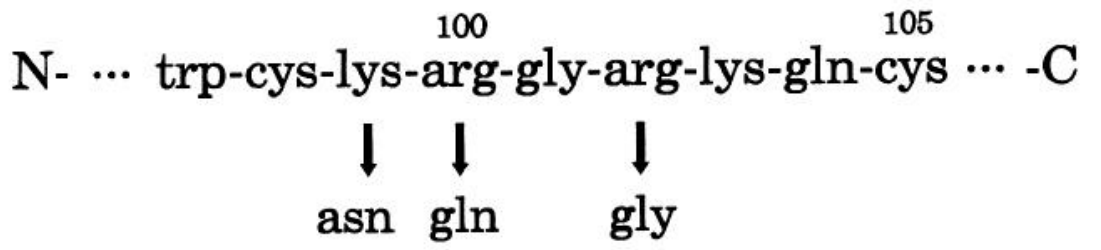

B
Figure 8. Site-directed mutagenesis of $\mathrm{APP}^{695} . A$, The plasmid expression vector pAPP-695 was mutated using two PCR steps. In the first PCR, the reverse primer (primer 2) contained the mutated sequence. PCR using primers 1 and 2 resulted in the amplification of a 212 bp fragment containing a unique AccI restriction site, which was then used to provide the forward primer for the second PCR using primer 3 as the reverse primer. The $1.7 \mathrm{~kb}$ fragment was then inserted back into the pAPP-695 at the AccI and BglII sites to yield the mutated plasmid (pAPP-hep). The thick bar shows the open reading frame, with the solid section representing the signal peptide sequence. The human cytomegalovirus promoter $\left(p_{c m}\right)$ was inserted between XhoI and BamHI sites. $S V 40$, Small t antigen intron and polyadenylation signal from SV40. The figure also shows the DNA sequence of the sense strand that was mutated and the changes in the amino acid sequence that resulted. $B$, Analysis of the binding of recombinant APPhep to a heparin affinity column by Western blotting. Conditioned medium from HeLa cells transfected with pAPP- 695 or pAPPhep was applied to a heparin column. The column was eluted with a linear gradient of $\mathrm{NaCl}(0-1.0 \mathrm{M})$ at a flow rate of $1.0 \mathrm{ml} / \mathrm{min}$ over $30 \mathrm{~min}$. One minute fractions were collected and each fraction analyzed by Western blotting using a monoclonal antibody (22C11) to APP. The band of $100 \mathrm{~K} \mathrm{M}$, was APP ${ }^{695}$. The band of $70 \mathrm{~K} M$, was an unidentified serum contaminant that cross-reacted with the monoclonal antibody. The peak of APP ${ }^{695}$ eluted in fraction 23 , whereas the peak of APPhep eluted in fraction 21. heparin column than the uncyclized peptide without the disulfide bond. In contrast, other peptides that were tested, including peptides homologous to other regions of APP containing clusters of basic residues (residues 317-331, 419-435, and 606-619 of the APP ${ }^{695}$ sequence), other peptide analogs of APP, and a peptide homologous to a heparin-binding domain in fibronectin (Hynes, 1985) either bound weakly to the column or did not bind at all.

The results of the heparin affinity chromatography suggested that the cyclized $\mathrm{APP}_{96-110}$ peptide bound to heparin far better than other peptides tested. To determine whether the cyclized $\mathrm{APP}_{96-110}$ peptide could inhibit the binding of APP to heparin, the binding of ${ }^{125}$ I-labeled human brain APP to heparin-coated 96-well plates was examined (Fig. 9). The cyclized APP $_{96-110}$ peptide was found to inhibit the specific binding of ${ }^{125}$ I-APP to heparin over a concentrations greater than $200 \mathrm{ng} / \mathrm{ml}\left(10^{-7} \mathrm{M}\right)$
(Fig. 9A). In contrast, two other basic peptides, $\mathrm{APP}_{317-331}$ and $\mathrm{APP}_{419-435}$, did not inhibit the binding of ${ }^{125}$ I-APP to heparin (Fig. 9B,C).

\section{Effect of $A P P_{96-110}$ peptide on neurite outgrowth}

As the $\mathrm{APP}_{96-110}$ peptide inhibited the binding of APP to heparin, we tested the ability of the cyclized heparin-binding peptide to block the effect of APP on neurite outgrowth. Chick sympathetic neurons were cultured as before on 24-well plastic plates precoated first with polyornithine and then with HSPG and APP, in the presence of various concentrations of the cyclized heparinbinding peptide (Fig. 10A). The data were analyzed by a oneway ANOVA and a Tukey test for multiple comparisons. The peptide significantly blocked $(P<0.05)$ the stimulation of neurite outgrowth caused by APP and P3 HSPG. In contrast, the uncyclized peptide did not block outgrowth, which suggested 
Figure 9. Effect of peptides on the binding of ${ }^{125}$ I-APP to heparin. Plastic 96-well ELISA plate wells were incubated with $0.1 \mathrm{ml}$ of $1 \mathrm{mg} / \mathrm{ml}$ of heparin $(0)$ or PBS (-), and then nonspecific binding sites were blocked with $1.0 \%$ BSA. Each well was incubated with ${ }^{125} \mathrm{I}$ APP $\left(7 \times 10^{5} \mathrm{dpm}\right)$ for $2 \mathrm{hr}$ at $37^{\circ} \mathrm{C}$. The amount of bound radioactivity eluted with Tris buffer containing 0.4 $\mathrm{M} \mathrm{NaCl}$ was measured in the presence of various concentrations of the cyclized $\mathrm{APP}_{40.10}$ peptide (A), $\mathrm{APP}_{317-331}$ $(B)$, and $\mathrm{APP}_{4: 9-435}(C)$. Points shown are means \pm SEM for three determinations.

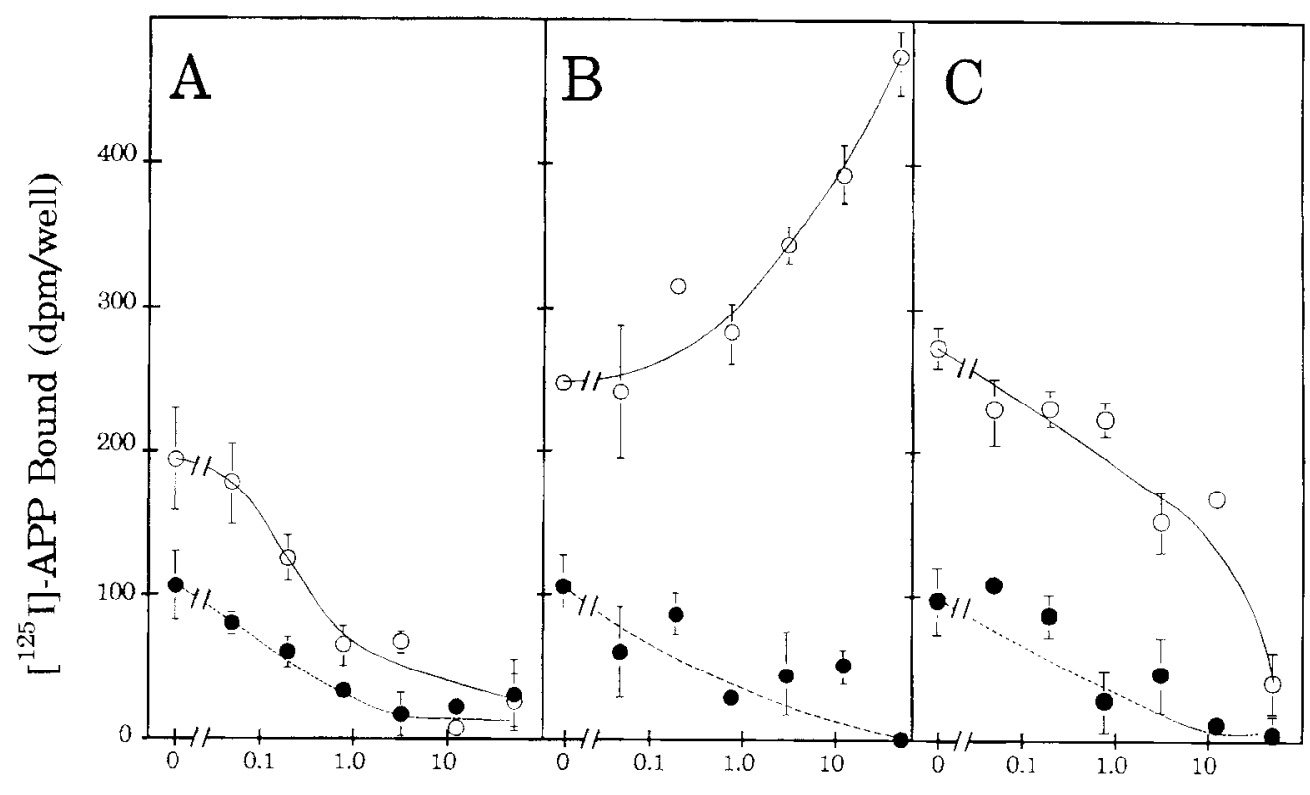

Concentration of Peptide ( $\mu \mathrm{g} / \mathrm{ml})$ that the conformation of the peptide was important for this effect. In addition, a control peptide homologous to the region of fibronectin involved in cell attachment, RGDS (Ruoslahti and Pierschbacher, 1986), had no effect on the ability of APP to stimulate neurite outgrowth.

In the presence of HSPG, substratum-bound APP also stimulated neurite outgrowth from dissociated hippocampal neurons prepared from embryonic (E18) mouse brain (Fig. 10B). The stimulation of hippocampal neurite outgrowth by APP was also blocked by the cyclized $\mathrm{APP}_{96-110}$ peptide. Again, the inhibitory effect of the peptide was specific, as the stimulation of neurite outgrowth was not blocked by the uncyclized form of this peptide, or by peptides corresponding to other domains in APP $\left(\mathrm{APP}_{317-331}\right.$ and $\left.\mathrm{APP}_{419-435}\right)$.

\section{Discussion}

The present study demonstrates that the binding of APP to ISPG is an important step in the regulation of neurite outgrowth. In this regard. APP may act in a similar fashion to several other heparin-binding molecules that become activated when bound to heparin or HSPGs. For example, basic FGF must first bind to HSPG before it can bind to a specific highaffinity cell surface receptor (Klagsbrun and Baird, 1991; Rapraeger et al., 1991; Yayon et al., 1991). Other heparin-binding proteins such as glia-derived nexin and antithrombin III are also activated by binding to heparin (Craig et al., 1989; Wallace et al., 1989).

The specificity of the effect of APP on neurite outgrowth is suggested by the fact that APP did not stimulate neurite outgrowth in our system as efficiently when added to the cultures in soluble form; thus, APP must be substrate-bound in vitro to exert its physiological effects. The binding to the substrate may mimic significant aspects of the binding of APP to the basement membrane. Our experiments do not indicate whether the effect of APP on neurite outgrowth is mediated through a mechanism involving increased cell adhesion to the substrate or via a specific cell surface receptor that transduces an intracellular response.
It was interesting that APP appeared to inhibit the action of laminin on neurite outgrowth, suggesting a dynamic role in altering the general adhesiveness of the environment. Thus, APP, like other molecules such as thrombospondin (Sun et al., 1992), may play subtle modulatory roles in altering the total cellular environment.

Previous studies have demonstrated the importance of basic residues in heparin binding (Villanueva, 1984; Cardin and Weintraub, 1989; Jackson et al., 1991). APP possesses three regions within its extracellular domain that are rich in basic residues. These regions of $\mathrm{APP}^{695}$ include residues $99-110$, residues $411-447$, and a previously defined region encoded within exon 9 (residues 317-331) (G. Multhaup, unpublished observations). Our experiments suggest that the domain between residues 99 and 110 (encoded within exon 3) possesses a functionally active heparin-binding capacity. The evidence for this conclusion can be summarized as follows. First, a $14 \mathrm{~K}$ polypeptide containing an $\mathrm{N}$-terminal epitope was found to bind to heparin columns. Second, an N-terminal domain was found to contain the consensus sequence for heparin binding proposed by Cardin and Weintraub (1989). Third, a peptide homologous to this region of the protein bound to a heparin affinity column as strongly as APP itself. The specificity of the binding of the peptide was supported by the observation that the affinity of the peptide for the heparin column was greater when the peptide was cyclized (i.e., constrained in a conformation similar to a predicted loop domain in APP). Fourth, mutagenesis of three residues (lysine-99, arginine-100, and arginine-102) predicted by molecular modeling to be important for a heparin-binding interaction decreased the heparin-binding capacity of APP. However, as the mutated protein (APPep) still bound to a heparin column (albeit with lower affinity), this indicated that other residues in the protein must also contribute to heparin binding. Fifth, the heparin-binding peptide very potently inhibited the effect of APP on neurite outgrowth, which was itself dependent upon the interaction of APP with HSPG. While it is conceivable that a trace contaminant could be responsible for this effect, this 
A

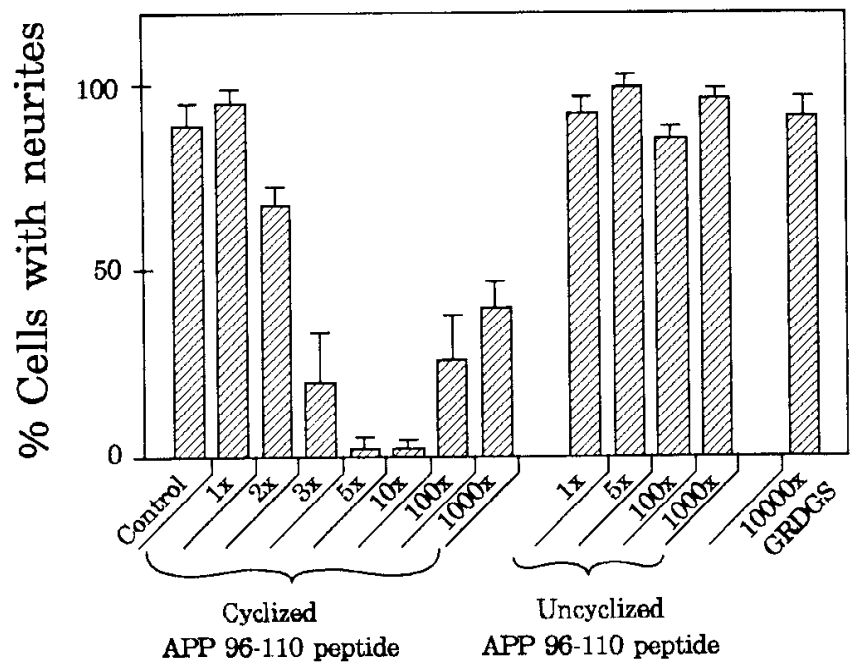

B

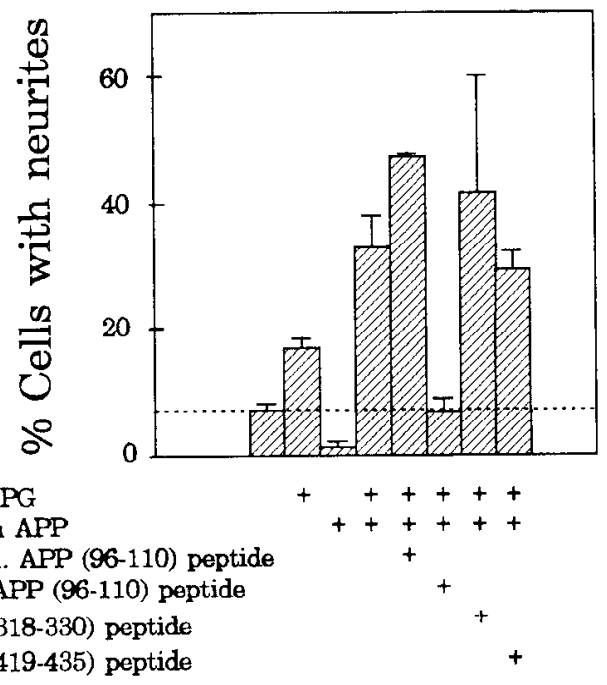

Figure 10. Effect of the cyclized APP (96-110) peptide on neurite outgrowth from E12 chick sympathetic $(A)$ and E18 mouse hippocampal neurons (B) maintained in culture for $48 \mathrm{hr}$. A, Plastic 24-well tissue culture plates were coated with polyornithine followed by bovine serum APP and P3 HSPG in the presence of various concentrations of the cyclized or uncyclized APP (96-110) peptide or a peptide (GRDGS) homologous to a region of fibronectin important for cell recognition. Control incubations were with no peptide added (PBS alone). The concentration of peptide added was from 1- to 10,000-fold over the concentration of APP on a molar basis. $B$, Tissue culture plates were coated with polyornithine followed by a combination of human brain APP, P3 HSPG, the uncyclized or cyclized APP (96-110) peptide, or peptides homologous to residues 317-331 or $419-435$ in the APP ${ }^{695}$ sequence (as shown). Peptides were incubated at a concentration of $10 \mu \mathrm{g} / \mathrm{ml}$ in PBS. Values are means of four determinations \pm SEM.

possibility is unlikely. Repurification of the peptide by reversedphase HPLC did not diminish its effect in cell culture (data not shown).

Our data also suggested that the type of HSPG may be critical for the neurite outgrowth-promoling effect of APP. While HSPG purified from cultures of $\mathrm{P} 3$ mouse brain neurons promoted the effect, HSPG purified from E10 mouse brain neurons (a developmental stage before the major phase of neurite outgrowth) did not support this effect. Consistent with this view, Herndon and Lander (1990) have shown that there is a large increase in both the amount and types of HSPG in the brain during early developmental periods. In our own studies (Nurcombe et al., 1993), we have found that developmental changes in the carbohydrate composition of HSPGs appear to regulate the presentation of FGF-1 and FGF-2 to neural cell surfaces. Thus, the preparation of $\mathrm{P} 3$ HSPG may contain a specific proteoglycan species that is required for the stimulation of neurite outgrowth by APP. The preparations used for the binding and cell culture experiments were mixtures of secreted forms of $\mathrm{HSPG}$. It is not yet possible to determine whether the effects observed are attributable to the binding of APP to onc or only a few HSPGs in the mixture.

Our finding that the interaction of substratum-bound APP with HSPG may be important for a physiological function of APP has implications for the pathogenesis of AD. HSPGs have been identified in amyloid plaques (Snow et al., 1988), although the significance of this finding is unclear. It is possible that the loss of synapses and neurites, known to occur in specific regions of the AD brain, may be related more to the loss of the normal trophic or neuroprotective influence of APP (Mattson et al., 1993) than to a neurotoxic effect of amyloid, as has been pro- posed (Yankner et al., 1989). Thus, it seems worthwhile to examine whether APP processed via an amyloidogenic pathway can exert the same trophic/neuroprotective influence on cells in culture as those forms of APP produced from the action of a normally functioning APP secretase. Altered interactions of APP with HSPGs may contribute to both the biochemical and pathologic changes that occur in AD.

\section{References}

Ausubel FM, Brent R, Kingston RE, Moore DD, Seidman JG, Smith JA, Struhl K (1992) Short protocols in molecular biology, 2d ed. New York: Wiley.

Breen KC (1992) APP-collagen interaction is mediated by a heparin bridge mechanism. Mol Chem Neuropathol 16:109-121.

Breen KC, Bruce M, Anderton BH (1991) Beta amyloid precursor protein mediates neuronal cell-cell and cell-surface adhesion. J Neurosci Res 28:90-100.

Cardin AD, Weintraub HJR (1989) Molecular modeling of proteinglycosaminoglycan interactions. Arteriosclerosis 9:21-32.

Chou PY, Fasman GD (1978) Prediction of the secondary structure of proteins from their amino acid sequence. Adv Enzymol 47:45148.

Chou PY, Fasman GD (1979) Prediction of $\beta$-turns. Biophys J 26: 367-384.

Craig PA, Olson ST, Shore JD (1989) Transient kinetics of heparincatalyzed protease inactivation by antithrombin. III. Characterization of assembly, product formation, and heparin dissociation steps in the factor Xa reaction. J Biol Chem 264:5452-5461.

De Sauvage F, Octave JN (1989) A novel mRNA of the A4 amyloid precursor gene coding for a possibly secreted protein. Science 245 : $651-653$.

Drago J, Nurcombe V, Bartlett PF (1991) Laminin through its long arm E8 fragment promotes the proliferation and differentiation of murine ncurocpithelial cells in vitro. Exp Cell Res 192:256-265.

Edgar D, Barde YA, Thoenen H (1981) Subpopulations of cultured 
chick sympathetic neurons differ in their requirements for survival factors. Nature 289:294-295.

Esch FS, Keim PS, Beattie EC, Blacher RW, Culwell AR, Oltersdorf T, McClure D, Ward PJ (1990) Cleavage of amyloid $\beta$ peptide during constitutive processing of its precursor. Science 248:1122-1124.

Glenner GG, Wong CW (1984) Alzheimer's disease: initial report of the purification of a novel cerebrovascular amyloid protein. Biochem Biophys Res Commun 120:885-890.

Golde TE, Estus S, Usiak M, Younkin LH, Younkin SG (1990) Expression of $\beta$ amyloid protein precursor mRNAs: recognition of a novel alternatively spliced form and quantitation in Alzheimer's disease using PCR. Neuron 4:253-267.

Goslin K, Banker G (1989) Experimental observations on the development of polarity by hippocampal neurons in culture. $\mathrm{J}$ Cell Biol 108:1507-1516.

Herndon ME, Lander AD (1990) A diverse set of developmentally regulated proteoglycans is expressed in the rat central nervous system. Neuron 4:949-961.

Hopp TP, Woods KR (1981) Prediction of protein antigenic determinants from amino acid sequences. Proc Natl Acad Sci USA 78: 3824-3828.

Hunter WM, Greenwood FC (1962) Preparation of iodine-131 labelled human growth hormone of high specific activity. Nature 194:495496.

Hynes R (1985) Molecular biology of fibronectin. Annu Rev Cell Biol 1:67-90.

Ishihara M, Guo Y, Swicdler SJ (1993) Selective impairment of the synthesis of basic fibroblast growth factor binding domains of heparin sulphate in a COS cell mutant defective in $N$-sulphotransferase. Glycobiol 3:83-88.

Jackson RL, Busch SJ, Cardin AD (1991) Glycosaminoglycans: molecular properties, protein interactions, and role in physiological processes. Physiol Rev 71:481-539.

Kang J, Lemaire HG, Unterbeck A, Salbaum JM, Masters CL, Grzeschik KH, Multhaup G, Beyreuther K, Muller-Hill B (1987) The precursor of Alzheimer's disease amyloid A4 protein resembles a cellsurface receptor. Nature 325:733-736.

Karplus PA, Schulz GF (1985) Prediction of chain flexibility in proteins. Naturwissenschaften 72:212-213.

Kitaguchi N, Takahashi Y, Tokushima Y, Shiojiri S, Ito H (1988) Novel precursor of $\Lambda$ lzheimer's disease amyloid protein shows protease inhibitory activity. Nature 331:530-532.

Klagsbrun M, Baird A (1991) A dual receptor system is required for basic fibroblast growth factor activity. Cell 67:229-231.

Klier FG, Cole G, Stallcup W, Schubert D (1990) Amyloid $\beta$-protein precursor is associated with extracellular matrix. Brain Res 515:336342.

König G, Mönning U, Czech C, Prior R, Banati R, Schreiter-Gasser U, Bauer J, Masters CL, Beyreuther K (1992) Identification and expression of a novel alternative splice isoform of the $\beta \mathrm{A} 4$ amyloid precursor protein (APP) mRNA in leukocytes and brain microglial cells. J Biol Chem 267:10804-10809.

Laemmli UK (1970) Cleavage of structural proteins during the assembly of the head of bacteriophage T4. Nature 227:680-685.

Masters CL, Simms G, Weinman NA, Multhaup G, McDonald BL, Beyreuther K (1985) Amyloid plaque core protein in Alzheimer disease and Down syndrome. Proc Natl Acad Sci USA 82:4245-4249.

Mattson MP, Cheng B, Culwell AR, Esch FS, Lieberburg I, Rydel RE (1993) Evidence for excitoprotective and intraneuronal calcium-regulating roles for secreted forms of the $\beta$-amyloid precursor protein. Neuron 10:243-254

Milward EA, Papadopoulos R, Fuller SJ, Moir RD, Small D, Beyreuther K, Masters CL (1992) The amyloid protein precursor of Alzheimer's disease is a mediator of the effects of nerve growth factor on neurite outgrowth. Neuron 9:129-137.

Moir RD, Martins RN, Bush AI, Small DH, Milward EA, Rumble BA, Multhaup G, Beyreuther K, Masters CL (1992) Human brain $\beta A 4$ amyloid protein precursor of Alzheimer's disease: purification and partial characterization. J Neurochem 59:1490-1498.

Narindrasorasak S, Lowery D, Gonzalez-DeWhitt P, Poorman RA, Greenberg B, Kisilevsky R (1991) High affinity interactions between the Alzheimer's $\beta$-amyloid precursor proteins and the basement mcmbrane form of heparan sulphate proteoglycan. J Biol Chem 266:1287812883 .

Narindrasorasak S, Lowery DE, Altman RA, Gonzalez-DeWhitt PA,
Greenberg BD, Kisilevsky R (1992) Characterization of high affinity binding between laminin and Alzheimer's disease amyloid precursor proteins. Lab Invest 67:643-652.

Needham LK, Adler R, Hewitt AT (1988) Proteoglycan synthesis in flat cell-free cultures of chick embryo retinal neurons and photoreceptors. Dev Biol 126:304-314.

Nurcombe V, Ford MD, Wildschut JA, Bartlett PF (1993) Developmental regulation of neural response to FGF-1 and FGF-2 by heparan sulphate proteoglycan. Science 260:103-106.

Palmert MR, Podlisny MB, Witker DS, Oltersdorf T, Younkin LH, Selkoe DJ, Younkin SG (1989) The $\beta$-amyloid protein precursor of Alzheimer's disease has soluble derivatives found in human brain and cerebrospinal fluid. Proc Natl Acad Sci USA 86:6338-6342.

Ponte P, Gonzalez-DeWhitt P, Schilling J, Miller J, Hsu D, Greenberg B, Davis K, Wallace W, Lieberburg I, Fuller F, Cordell B (1988) A new A4 amyloid mRNA contains a domain homologous to scrine protease inhibitors. Nature 331:525-527.

Potempska A, Styles J, Mehta P, Kim KS, Miller DL (1991) Purification and tissue level of the $\beta$-amyloid peptide precursor of rat brain. J Biol Chem 266:8464-8469.

Raj NBK, Israeli R, Kelley KA, Leach SJ, Minasian E, Sikaris K, Parry DAD, Pitha PM (1988) Synthesis, antiviral activity and conformational characterization of mouse-human $\alpha$-interferon hybrids. J Biol Chem 263:8943-8952.

Rapraeger AC, Krufka A, Olwin BB (1991) Requirement of heparan sulphate for bFGF-mediated fibroblast growth and myoblast differentiation. Science 252:1705-1708.

Roch JM, Shapiro IP, Sundsmo MP, Otero DAC, Refolo LM, Robakis NK, Saitoh T (1992) Bacterial expression, purification, and functional mapping of the amyloid $\beta / A 4$ protcin precursor. J Biol Chem 267:2214-2221.

Ruoslahti E, Pierschbacher MD (1986) Arg-gly-asp: a versatile cell recognition signal. Cell 44:517-518.

Saitoh T, Sundsmo M, Roch JM, Kimura N, Cole G, Schubert D, Oltersdorf T, Schenk DB (1989) Secreted form of amyloid $\beta$ protein precursor is involved in the growth regulation of fibroblasts. Cell 58 : 615-622.

Schubert D, Cole G, Saitoh T, Oltersdorf T (1989a) Amyloid beta protein precursor is a mitogen. Biochem Biophys Res Commun 162: 83-88.

Schubcrt D, Jin LW, Saitoh T, Cole G (1989b) The regulation of amyloid $\beta$ protein precursor secretion and its modulatory role in cell adhesion. Neuron 3:689-694.

Schubert D, LaCorbiere M, Saitoh T, Cole G (1989c) Characterization of an amyloid $\beta$ precursor protein that binds heparin and contains tyrosine sulphate. Proc Natl Acad Sci USA 86:2066-2069.

Sikaris K, Minasian E, Leach SJ, Flegg R (1989) Computer program designed to predict and plot the secondary structure of proteins. Comput Appl Biosci 5:323.

Sisodia SS, Koo EH, Beyreuther K, Unterbeck A, Price DL (1990) Evidence that $\beta$-amyloid protein in Alzheimer's disease is not derived by normal processing. Scicncc 248:492-495.

Slatko BE, Albright LM (1992) DNA sequencing. In: Short protocols in molecular biology (Ausubel FM, Brent R, Kingston RE, Moore DD, Seidman JG, Smith SA, Struhl K, eds), pp 7.1-7.53. New York: Wiley.

Small DH, Moir RD, Fuller SJ, Michaelson S, Bush AI, Li QX, Milward E, Hilbich C, Weidemann A, Beyreuther K, Masters CL (1991) A protease activity associated with acetylcholinesterase releases the membrane-bound form of the amyloid protein precursor of Alzheimer's disease. Biochemistry 30:10795-10799.

Small DH, Nurcombe V, Moir R, Michaelson S, Monard D, Beyreuther K, Masters CL (1992) Association and release of the amyloid protein precursor of Alzheimer's disease from chick brain extracellular matrix. J Neurosci 12:4143-4150.

Snow AD, Mar H, Nochlin D, Kimata K, Kato M, Suzuki S, Hassell J, Wight TN (1988) The presence of heparan sulphate proteoglycans in the neuritic plaques and congophilic angiopathy in Alzheimer's disease. Am J Pathol 133:456-463.

Sun X, Skorstengaard K, Mosher DF (1992) Disulfides modulate RGDinhibitable cell adhesive activity of thrombospondin. J Cell Biol 118: 693-701.

Tanzi RE, McClatchey AI, Lamperti ED, Villa-Komaroff L, Gusella JF, Neve RL (1988) Protease inhibitor domain encoded by an amyloid 
protein precursor mRNA associated with Alzheimer's disease. Nature 331:528-530.

Threlkeld A, Adler R, Hewitt AT (1989) Proteoglycan synthesis by chick embryo retina glia-like cells. Dev Biol 132:559-568.

Villanueva GB (1984) Predictions of the secondary structure of antithrombin III and the location of the heparin-binding site. J Biol Chem 259:2531-2536.

Wallace A, Rovelli G, Hofsteenge J, Stone SR (1989) Effect of heparin on the glia-derived-nexin-thrombin interaction. Biochem J 257:191196.

Weidemann A, König G, Bunke D, Fischer P, Salbaum JM, Masters CL, Beyreuther K (1989) Identification, biogenesis, and localization of precursors of Alzheimer's disease A4 amyloid protein. Cell 57: $115-126$

Whitson JS, Selkoe DJ, Cotman CW (1989) Amyloid $\beta$ protein enhances the survival of hippocampal neurons in vitro. Science 243: 1488-1490.
Whitson JS, Glabe CG, Shintani E, Abcar A, Cotman CW (1990) $\beta$-Amyloid protein promotes neuritic branching in hippocampal cultures. Neurosci Lett 110:319-324.

Yanagishita M, Hascall VC (1984) Proteoglycans synthesized by rat ovarian granulosa cells in culture: isolation, fractionation and characterization of proteoglycans associated with the cell layer. J Biol Chem 259:10260-10269.

Yankner BA, Dawes LR, Fisher S, Villa-Komaroff L, Oster-Granite ML, Neve RL (1989) Neurotoxicity of a fragment of the amyloid precursor associated with Alzheimer's disease. Science 245:417-420.

Yayon A, Klagsbrun M, Esko JD, Leder P, Ornitz DM (1991) Cell surface, heparin-like molecules are required for binding of basic $\mathrm{fi}$ broblast growth factor to its high affinity receptor. Cell 64:841-848.

Yoshikawa K, Aizawa T, Hayashi Y (1992) Degeneration in vitro of post-mitotic neurons overexpressing the Alzheimer amyloid protein precursor. Nature 359:64-67. 